\title{
Application of the Double Diamond framework to prepare the communication strategy of a great sports event
}

\author{
Michal Jilka \\ Faculty of Sports Studies, Masaryk University, Brno
}

\begin{abstract}
Any sports event is characterized by the process of planning, organization and implementation and evaluation itself. This system applies to both single and repetitive, small or larger sports events. The planning process itself applies to all components - sports, technical, financial, process-law, and marketing communications.

There are several marketing communication goals, but they all focus on end-users, fans, their desires, needs and interests in each sporting event. To maximize the benefits of marketing communications, careful preparation and a creative concept in the editorial plan must be prepared.

Different procedures are used to prepare the communication strategy. This article aims to introduce the universal Double Diamond framework, which was used to prepare the communication strategy on the web and social medias for the World Cup in biathlon in Nové Město na Moravě held from December 20 to December 23, 2018, to familiarize with the possibilities of using social tools networks and to present the results achieved with these instruments.

This study describes the framework theoretically and then shows possible practical outputs from the whole process.
\end{abstract}

Keywords: sport, sports event, fans, biathlon, marketing, marketing communication, communication strategy, double diamond

\section{INTRODUCTION}

Marketing communication involves the sharing of meaning, information and concepts from the source and the receiver about the products and services through the devices of promotion through advertising, publicity, salesmanship and sales promotion (Rohini, 2018).

According to Přikrylová \& Jahodová (2010) there is a several objectives of marketing communications: provide information, create and stimulate demand, different your product or service, emphasize the benefit and value of the product, build and grow a brand or strengthen corporate image.

With the rise of internet communications and mostly social networks, there is growing demand for regular and immediate awareness of the fans. They are usually looking information on the event's website and Facebook page.

Biathlon in the Czech Republic experienced a huge boom mainly thanks to the performance of Czech representatives like Gabriela Koukalová (born Soukalová), Ondřej Moravec, Michal Šlesingr or Veronika Vítková (Hančl, 2017). World Cup races in the year 2016 visited 123,500 fans in four days (Líbal \& Mikeš, 2016).

And a similar visit was also expected in December 2018. Especially this enormous interest of fans has prompted the need for quality communication through web sites and social networks. The entire communication strategy on the web, Facebook and Instagram was created to activate biathlon fans before the start of World Cup competitions in Nové Město na Moravě and provide them information about important aspects related to the arrival and the actual stay in Vysočina Arena.

The whole communication concept was created through the Double Diamond framework. 


\section{METHODS}

Double diamond (Figure 1) is a framework of managing divergent and convergent thought models to create a flow between research, development and design techniques and is also used to create communication strategies (Nessler, 2018; Stubbs, 2018).

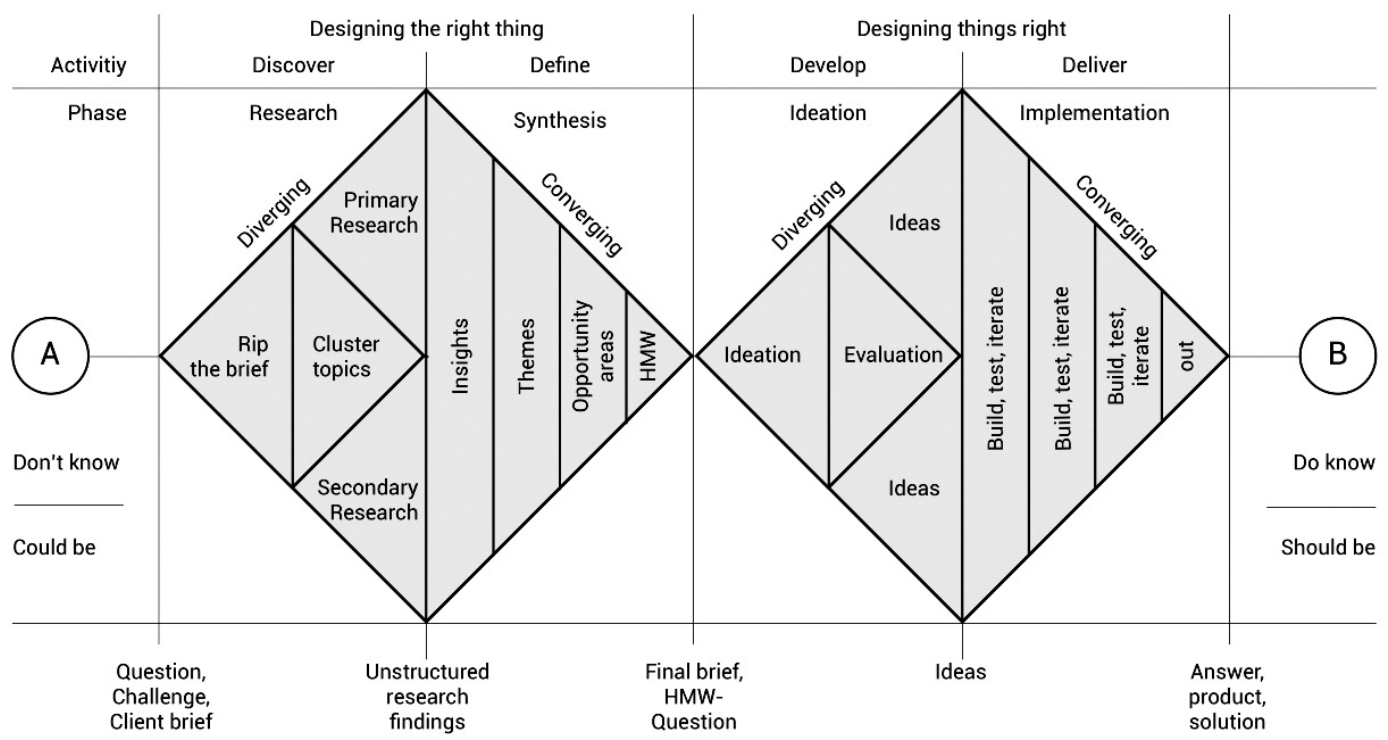

Fig. 1: Double Diamond framework (Nessler, 2018)

As can be seen in the figure, the framework consists of four phases:

- Research Phase,

- Synthesis Phase,

- Ideation Phase,

- Implementation Phase.

Research Phase (Discover) is the first step of the whole process and is based on a written brief describing the starting situation, description of goals, costs, tools, timing and responsible persons. Another part of this phase is also research - marketing mix, definition of our customer or clients, position on the marketing, our competitors etc. The following research methods were also used for this phase: desk research - evaluation the web data from Google Analytics and statistics from Facebook page and Instagram page and also evaluation competitor's qualitative data (the quality of web site, amount of Facebook status and Instagram pages, used tools), and traffic analysis.

The second is Synthesis Phase (Define) and starts with definition of personas (personas are archetypical users whose goals and characteristics represent the needs of a larger group of users) (Babich, 2017). For definition of personas were used brainstorming and brainwriting. In case of misunderstanding, the Dot voting was used for clear solution. Dot voting is marketing method that is used when the team needs to choose one option from multiple options (Zbiejczuk Suchá, 2018). The next step of this phase was definition Customer journey map. Customer journey map describes the customer's experience on every single communication channel we used (Boag, 2018). Important part of customer journey is also an empathy map (Figure 2). An empathy map is a collaborative tool teams can use to gain a deeper insight into their customers. Much like a user 
persona, an empathy map can represent a group of users, such as a customer segment (Bland, 2016). The last step of Synthesis Phase was to define How might we questions. These questions define the specific opportunities and tasks we are trying to solve in next phase of this framework (Libdesign, 2018).

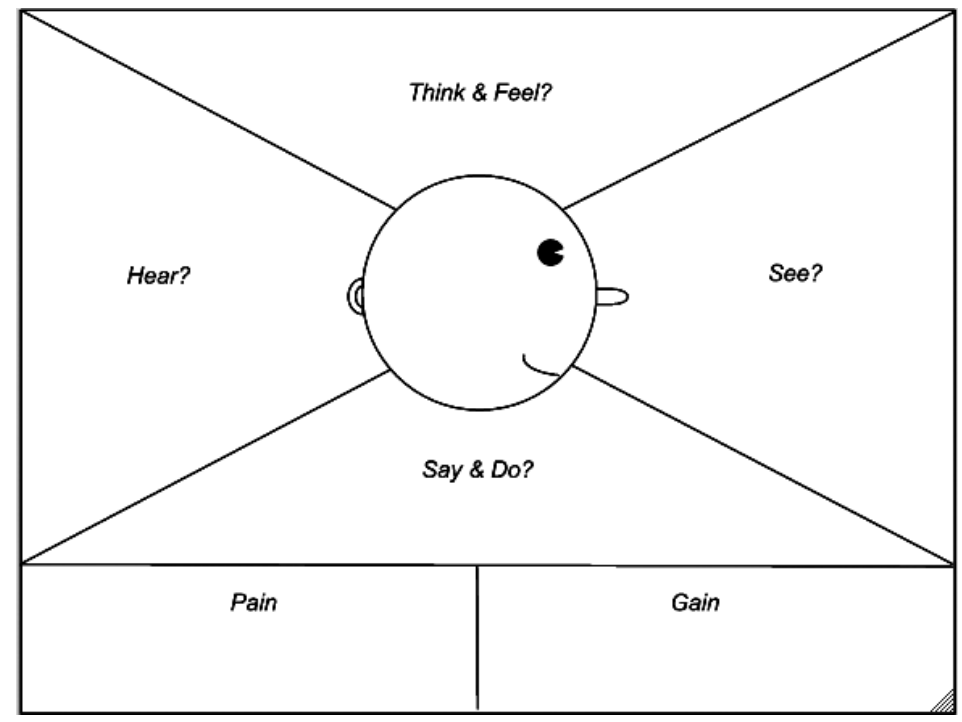

Fig. 2: Empathy Map (Bland, 2016)

After defining How might we questions, we approach Ideation Phase (Develop). This creative phase is primarily about finding answers to HMW questions. A few rounds of brainstorming and brainwriting were used like a research method. Process for generating creative ideas and solutions through intensive and freewheeling group discussion. Every participant is encouraged to think aloud and suggest as many ideas as possible, no matter seemingly how outlandish or bizarre. Analysis, discussion, or criticism of the aired ideas is allowed only when the brainstorming session is over and evaluation session begins (BusinessDictionary, 2019). Brainwriting is a technique similar to brainstorming, but the general process is that all ideas are recorded by the individual who thought of them. They are then passed on to the next person who uses them as a trigger for their own ideas (Mycoted, 2019). The decisions and the final draft of communication strategy was created through Dot voting.

The last phase of Double Diamond is called Implementation Phase (Deliver). This phase is about concretizing individual elements of every strategy we have chosen to create. It contains several rounds of suggestions, testing and approving posts, graphics, voting, etc. All suggestions were then put into a detailed editorial plan and applied to individual communication channels. 


\section{RESULTS}

The assignment of the entire project was to create a communication strategy from November $1^{\text {st }}$ to December $24^{\text {th }}$ for Biathlon NMNM, its website (www.biathlonnmnm.cz) and social medias Facebook (https://www.facebook.com/biathlonnmnm/) and Instagram (https://www.instagram. com/biathlonnmnm.cz/).

The main goal was to activate fans on social networks and to provide enough information through the website. Partial goals for social networks were defined:

- Increase the average organic reach to a post on the Facebook from current 630 users to the least 5,000 users.

- Increase the average response to a post on the Facebook from current 10 to the least 300.

- Increase the followers on the Instagram page from 800 to the least 2,000 followers.

- Gain the organic responses to a post on the Instagram to the least 200.

According to several brainstorming a brainwriting activities (Figure 3), the whole strategy was created for these personas:

\section{Š́rka}

- Age: 15

- Job: student

- Marital status: single

- User of social media: very active

- Hobbies: friends, dance, skiing,

- Biathlon fan - active participate with her family and friends. She wants to see all information and photo with her favorite athletes Martin Fourcade and Johannes Thingnes Boe. She is waiting for autographs and photos after the race.

\section{Radim}

- Age: 21

- Job: student

- Marital status: single

- User of social media: very active

- Hobbies: active athlete, mostly winter sports and jogging

- Biathlon fan - active participate during the races, buying merchandise, follower of all social media about biathlon, he wants to have all information about current situation, arrangement, athletes etc.

\section{Monika}

- Age: 27

- Job: Receptionist in the fitness center

- Marital status: single

- User of social media: very active

- Hobbies: recreational athlete, education, books

- Biathlon fan: huge fan, active participant with a whole family and her boyfriend - they spend all four days in Nové Město na Moravě, buying merchandise. She is follower of all social media, but she is active just on Instagram. She wants to see biathletes and backstage, that fans can't see. 


\section{Petra}

- Age: 35

- Job: financial accountant

- Marital status: married

- User of social media: passive

- Hobbies: family, friends, skiing

- Biathlon fan: passive participant, she visits the races with a family, organizes a whole trip and stay in Nové Město na Moravě. She takes care of her children who love biathlon as well as her husband. She needs to know all information about traffic and parking, accommodation, race program, also history of races etc.

\section{Martin}

- Age: 43

- Job: marketing manager

- Marital status: married

- User of social media: active

- Hobbies: friends, music, cheering on big sports events

- Biathlon fan: big, he wants to know all necessary information including news about Czech team and the biggest stars of world biathlon. He visits the races with his friends, he wants to enjoy the great atmosphere in Vysočina Arena.

We also excluded two personas from the process, due to low social activity on social network, because that we had to focus on the goal of the entire strategy. But these personas could be included in other marketing activities.

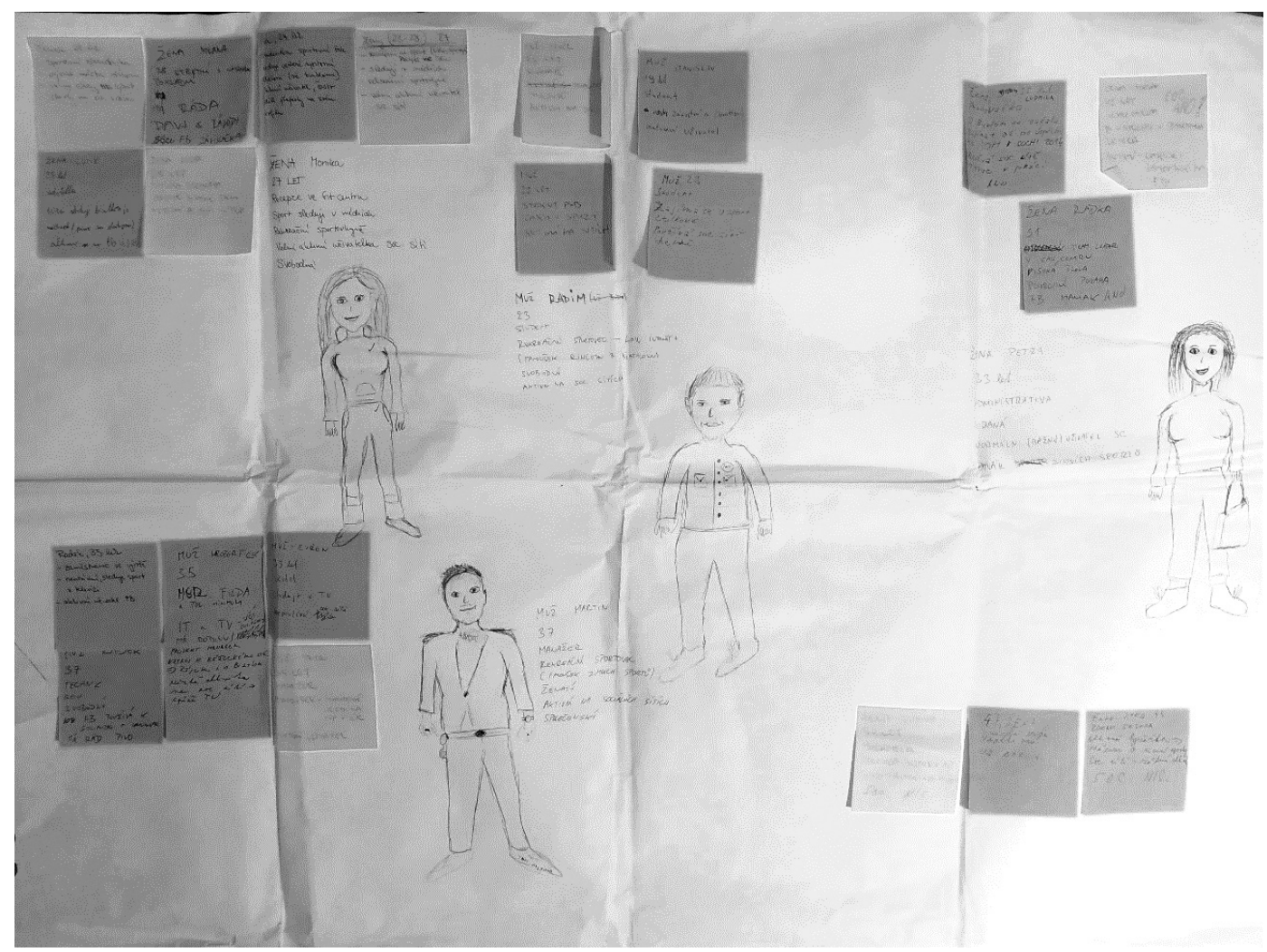

Fig. 3: Creating personas 
After personas definition, the customer journey was created. The entire customer journey (Table 1) is tailored to the needs of the project - the goals and especially the personas.

Tab. 1: Customer journey

\begin{tabular}{|c|c|c|c|c|}
\hline & Awareness & $\begin{array}{l}\text { Consideration } \\
\text { and purchase }\end{array}$ & Acquisition & Service and care \\
\hline $\begin{array}{l}\text { What are } \\
\text { they doing } \\
\text { on social } \\
\text { network? }\end{array}$ & $\begin{array}{l}\text { - high contribution } \\
\text { reach } \\
\text { - sharing, comments } \\
\text { from friends } \\
\text { - hashtags } \\
\text { - recommended posts }\end{array}$ & $\begin{array}{l}\text { - program search and } \\
\text { schedule } \\
\text { - search for informa- } \\
\text { tion about transpor- } \\
\text { tation, parking and } \\
\text { accommodation } \\
\text { - what to take to the } \\
\text { arena }\end{array}$ & $\begin{array}{l}\text { search for informa- } \\
\text { tion about tickets, } \\
\text { arenas, and tribunes } \\
\text { online ticket pur- } \\
\text { chase } \\
\text { - online purchase of } \\
\text { promotional items }\end{array}$ & $\begin{array}{l}\text { - return ticket infor- } \\
\text { mation } \\
\text { - message response } \\
\text { - ticket delivery }\end{array}$ \\
\hline $\begin{array}{l}\text { Empathy } \\
\text { Map }\end{array}$ & $\begin{array}{l}\text { - interest } \\
\text { - enthusiasm } \\
\text { - a new opportunity } \\
\text { - curiosity }\end{array}$ & $\begin{array}{l}\text { - understanding } \\
\text { - } \text { curiosity } \\
\text { - } \text { surprise } \\
\text { - search } \\
\text { - confusion } \\
\text { - } \text { surprise }\end{array}$ & $\begin{array}{l}\text { - enthusiasm } \\
\text { - joy } \\
\text { - enjoyment } \\
\text { - entertainment }\end{array}$ & $\begin{array}{l}\text { - } \text { satisfaction } \\
\text { - positive feedback } \\
\text { - annoyance in case } \\
\text { of non-compliance }\end{array}$ \\
\hline $\begin{array}{l}\text { What do we } \\
\text { want people } \\
\text { to do there? }\end{array}$ & $\begin{array}{l}\text { - to gain awareness } \\
\text { - raising interest } \\
\text { - brand search }\end{array}$ & $\begin{array}{l}\text { - easy orientation } \\
\text { - available informa- } \\
\text { tion } \\
\text { - raising positive feel- } \\
\text { ings } \\
\text { - quality presenta- } \\
\text { tions }\end{array}$ & $\begin{array}{l}\text { - simple purchase of } \\
\text { tickets } \\
\text { - buying merchandis- } \\
\text { ing } \\
\text { - quality service and } \\
\text { product } \\
\text { - discounts for part- } \\
\text { ners } \\
\text { - experience from the } \\
\text { atmosphere }\end{array}$ & $\begin{array}{l}\text { - immediate answers } \\
\text { - immediate receipt } \\
\text { of tickets } \\
\text { - good information } \\
\text { - true information } \\
\text { - friendliness }\end{array}$ \\
\hline $\begin{array}{l}\text { Opportunities } \\
\text { we have }\end{array}$ & $\begin{array}{l}\text { - great sharing of } \\
\text { posts } \\
\text { - viral video } \\
\text { - stories of represen- } \\
\text { tatives } \\
\text { - stories about biath- } \\
\text { lon events in the } \\
\text { Vysočina Arena }\end{array}$ & $\begin{array}{l}\text { - video with invita- } \\
\text { tions of representa- } \\
\text { tives } \\
\text { - an article with in- } \\
\text { formation on what } \\
\text { to take with to take } \\
\text { - virtual map of the } \\
\text { premises } \\
\text { - virtual parking map }\end{array}$ & $\begin{array}{l}\text { - purchase directly } \\
\text { on Facebook } \\
\text { - share your NMNM } \\
\text { experiences } \\
\text { - activating partner- } \\
\text { ships with partners }\end{array}$ & $\begin{array}{l}\text { - direct messages on } \\
\text { Messenger } \\
\text { - informing fans } \\
\text { through the app }\end{array}$ \\
\hline
\end{tabular}

The next step was to define "How might we questions" (HMW). After several rounds of brainwriting, 20 possible creative ideas were created. With the help of Dot voting, they were determined HMW questions:

1. How might we use social media tools to get the great fans interaction on social media?

2. How might we increase engagement on social media with the help of Czech representation?

3. How might we give our fans enough information?

After defining HMW questions, the creative process followed. Each question was devised with several ideas (Figure 4). 


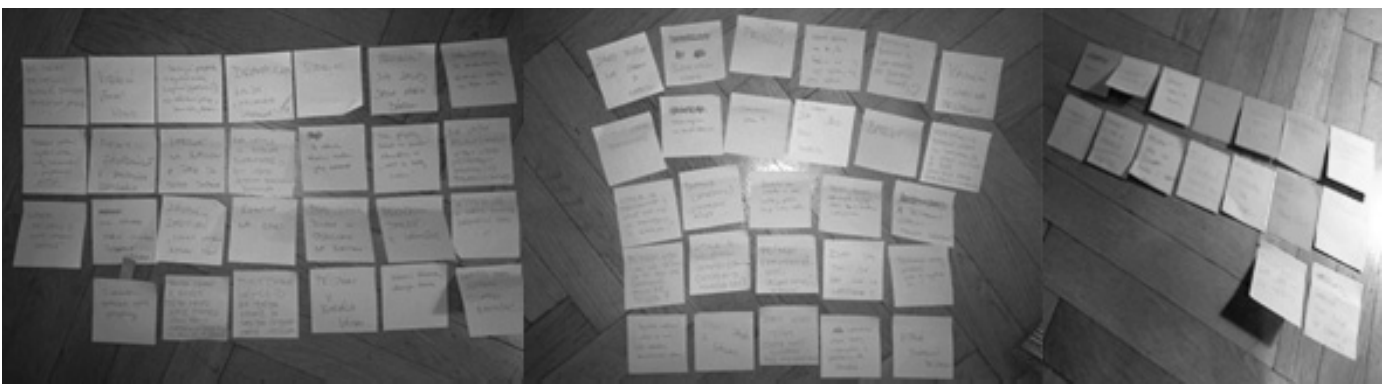

Fig. 4: Creative process

Created strategies:

$H M W$ q. 1

- Emoji voting - example: a favorite color combination of a new hat

- Comments - example: write us your comments about what favorite song you want to sing at the stadium together

- Connection Instagram and Facebook to direct share photos and stories - example: countdown of 10 day before the start of the race (Figure 5)

- Cross posting of videos made by International Biathlon Union (IBU) - example: course overview with Eva Puskarčíková (Figure 6)

- Videos - example: favorite NMNM song

- Using hashtags - examples: \#nmnm2018, \#biathlonnmnm, \#celebratingbiathlon (Figure 5)

- Stories voting on Instagram through a survey or scale (Figure 7)

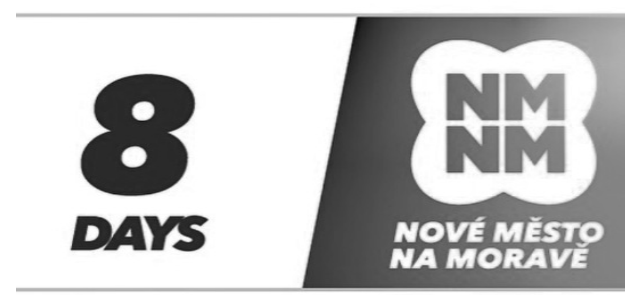

Zobrazit přehledy

Propagovat

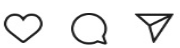

116 To se mi líbi

biathlonnmnm.cz 8!!! S kým se do NMNM chystáte? (6) \#biathlonnmnm \#biathlon \#celebratingbiathlon \#nmnm2018

Zobrazit všechny komentáře (8)

Fig. 5: Countdown sample

Source: Instagram page biathlonnmnm.cz

\section{Biathlon NMNM}

Mrkněte se na $2,5 \mathrm{~km}$ okruh v podání Eva Puskarčíková a M arkéta Davidová. .. Celé video najdete zde httos $: / w w w$ youtube com/watch?v=-_GQuDUWyA

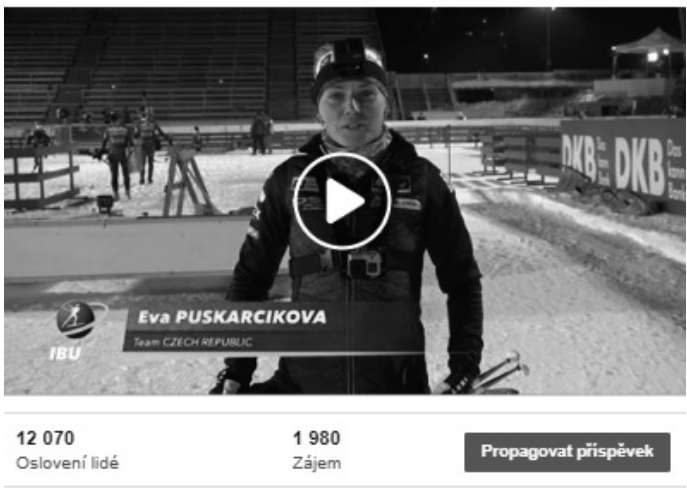

(1) 198

2 komentárü 10 sdileni 17 tis. tłlédnuti

đTose ni libíi $\square$ Konentár $\quad \Rightarrow$ Sdilet

Fig. 6: Cross posted video made by IBU Source: Facebook page Biathlon NMNM 


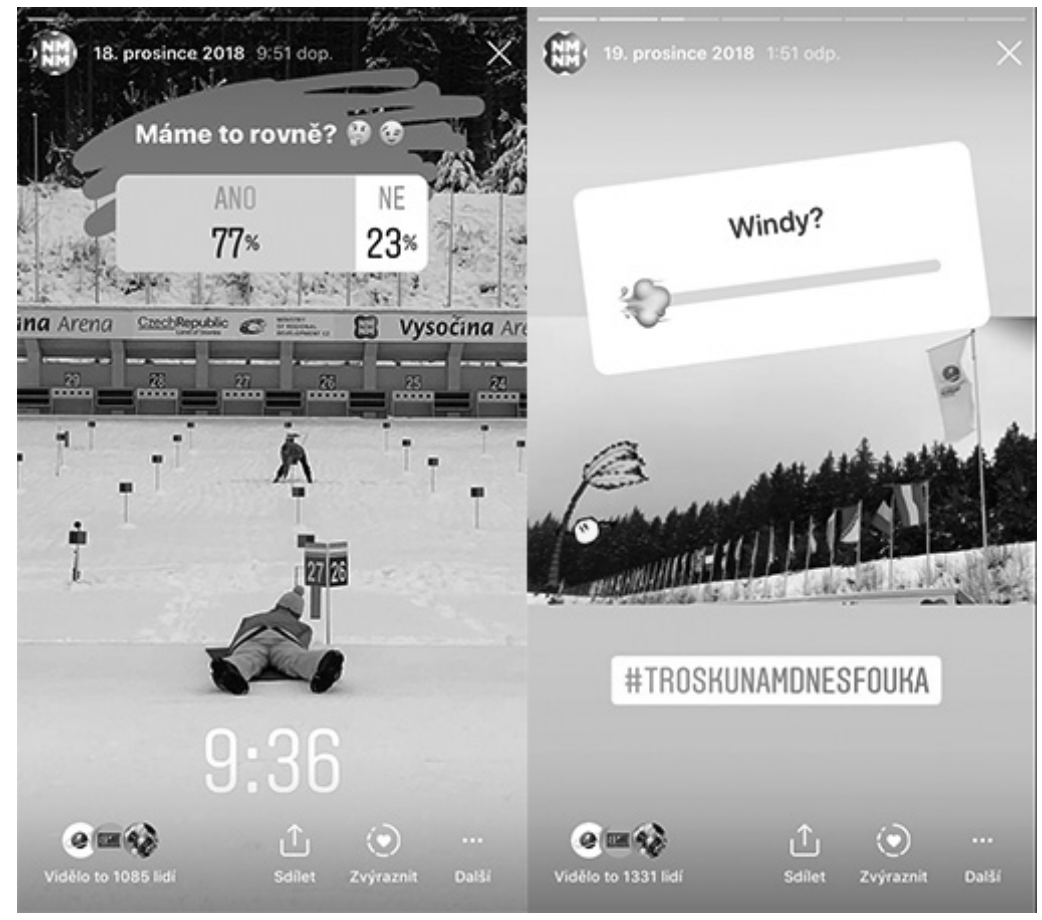

Fig. 7: Stories samples

Source: Instagram page biathlonnmnm.cz

$H M W q .2$

- Interview with Czech representative

- Creating an invitation from the Czech team for Czech fans

- Leaving Instagram profile to Czech representatives for one day

- Marking Czech or other athletes in posts or stories

$H M W$ q. 3

- Creating a virtual parking map

- Writing an article about what to take and to do in Vysočina Arena

- A series of articles about historical events in Vysočina Arena

- Writing an article about snow storage and track preparation

- Creating a Biathlon FunCard and sharing for fans

All ideas from strategies were transformed to the posts and stories on Facebook and Instagram, and to the articles on the website. Each specific post was insert into the editorial plan (Figure 8). According to this plan were all posts published until December $24^{\text {th }}$. 


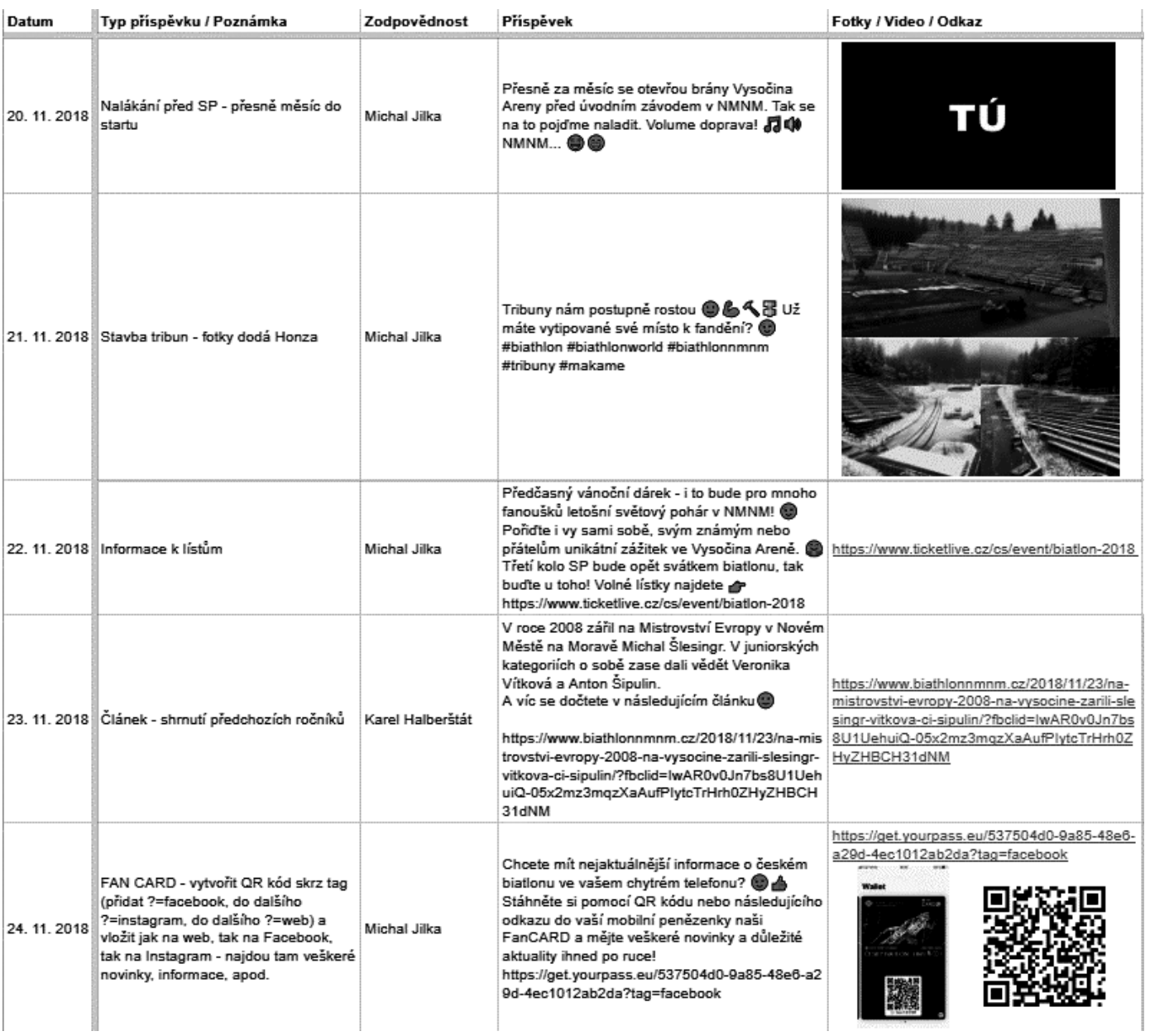

Fig. 8: Illustration of editorial plan

After the end of the World Cup in the biathlon in Nové Město na Moravě, the evaluation of the selected strategies followed. According to data from Facebook and Instagram, the chosen strategies were successful:

Partial goal 1: Increase the average organic reach to a post on the Facebook from current 630 users to the least 5,000 users - according to data from Facebook (Figure 9), we increased the average organic reach to more than 15,000 users. 


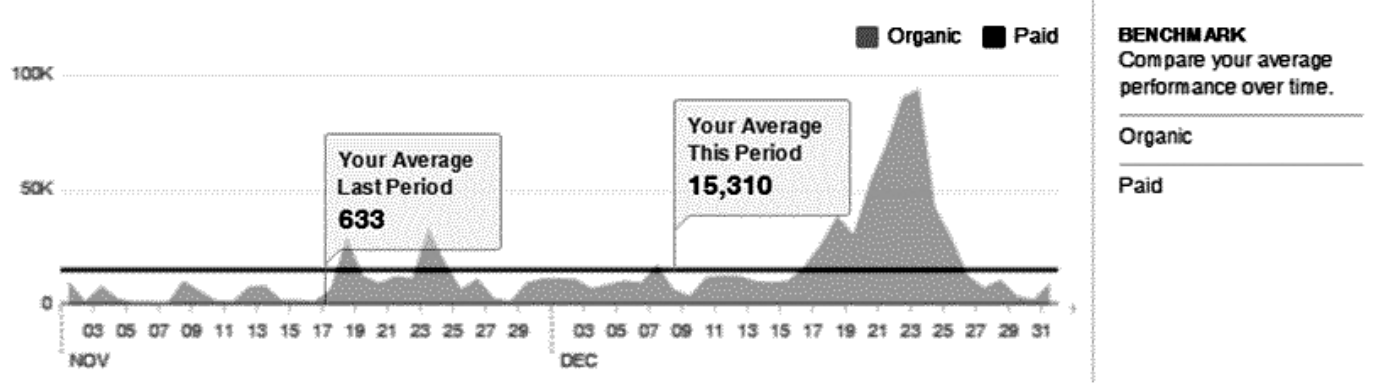

Fig. 9: Organic reach between November $1^{\text {st }}$ and December $31^{\text {st }}$ Source: data from Facebook Biathlon NMNM

Partial goal 2: Increase the average response to a post on the Facebook from current 10 to the least 300 - according to data from Facebook (Figure 10), we increased the average response to almost 500 per post.

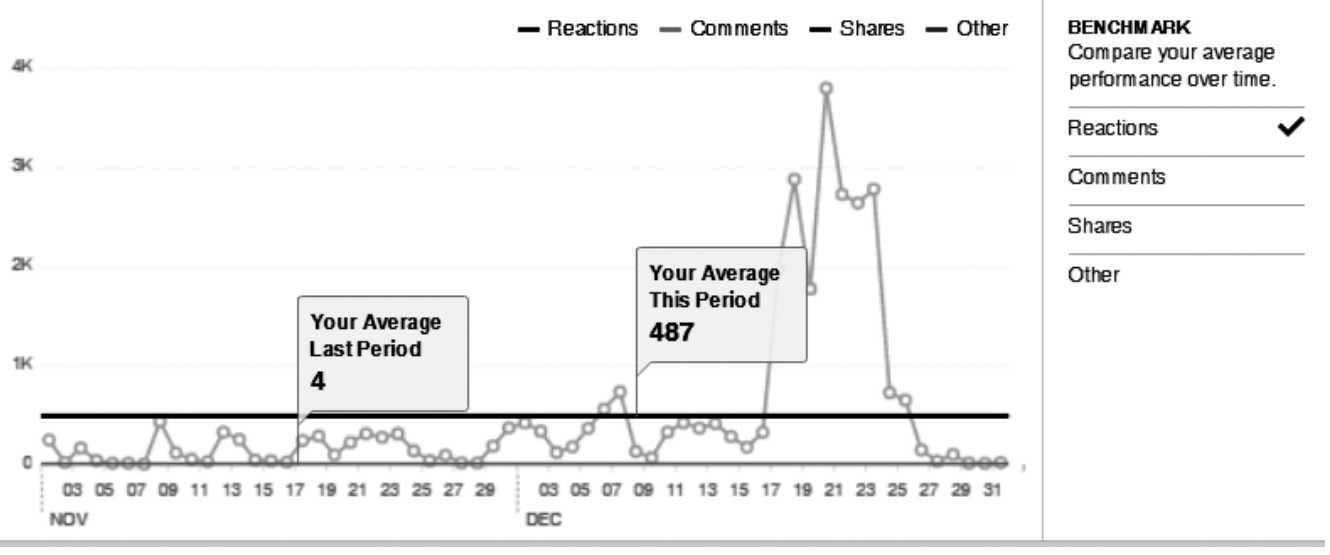

Fig. 10: Average reactions to a post between November $1^{\text {st }}$ and December $31^{\text {st }}$

Source: data from Facebook Biathlon NMNM

Partial goal 3: Increase the followers on the Instagram page from 800 to the least 2,000 followers - according to data from Instagram (Figure 11), we increased the number of followers from 800 to more than 2,200 (data from January 2nd). On January 13th, the profile has a total of 2,510 followers. 


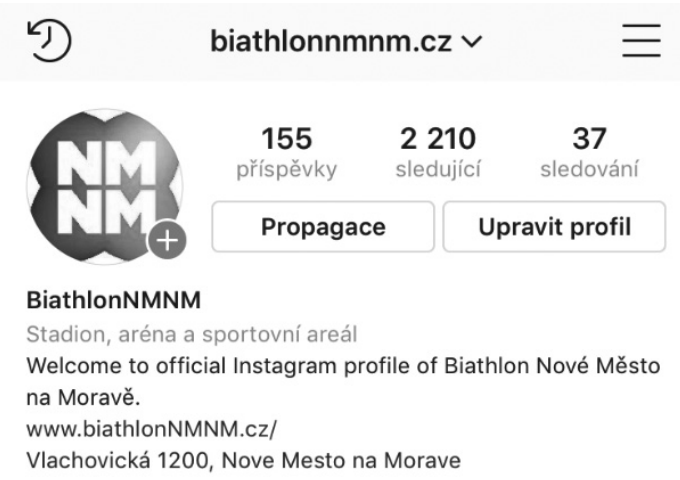

Fig. 11: The number of followers on Instagram on January $2^{\text {nd }}$ Source: Instagram page biathlonnmnm.cz

Partial goal 4: Gain the organic responses to a post on the Instagram to the least 200 - according to image data from Instagram (Figure 12), between November $1^{\text {st }}$ and December $24^{\text {th }}$ were published 47 posts, 13 posts received a lower response than required 200 . That means $72,34 \%$ of posts reached the goal. 


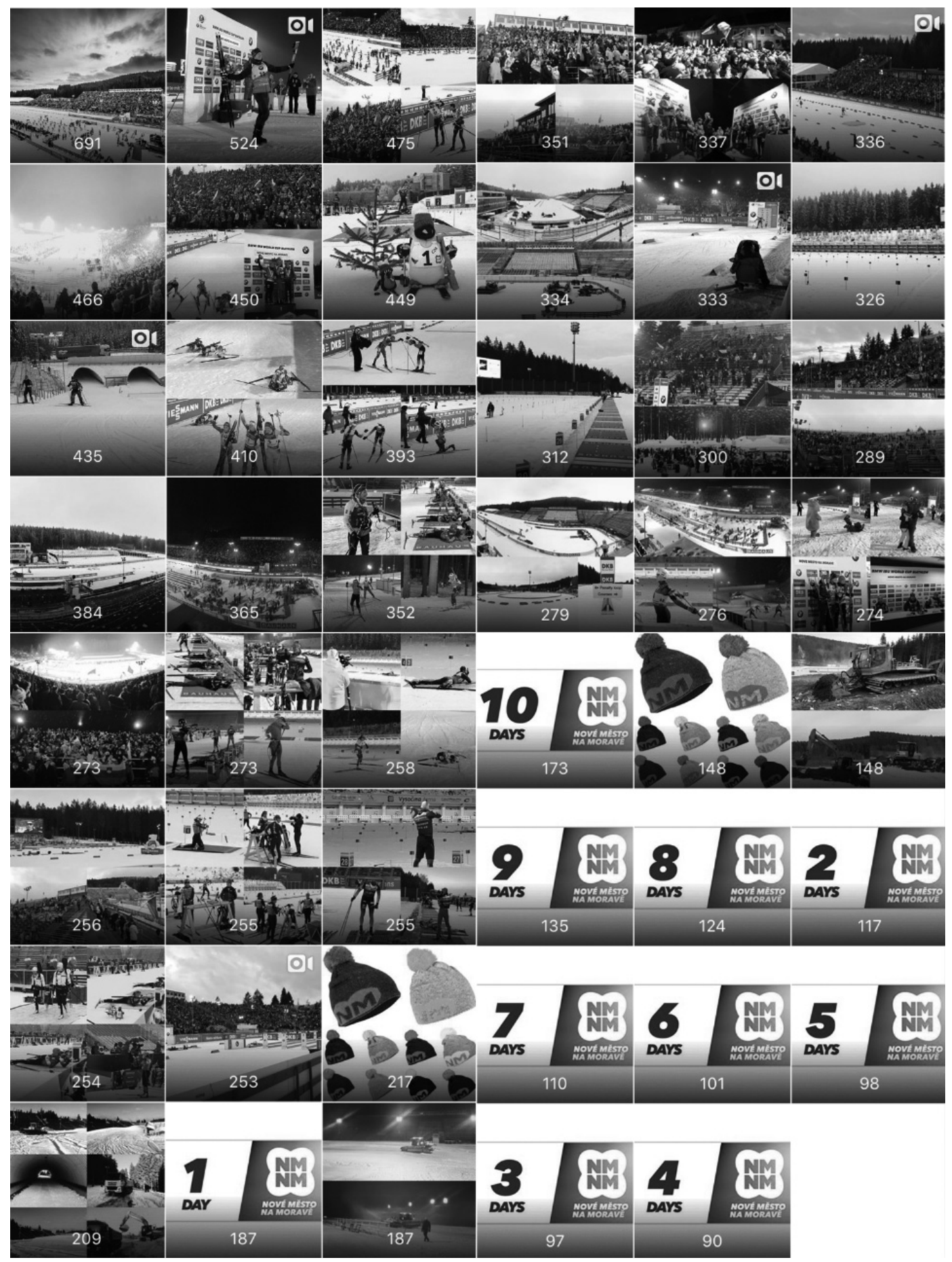

Fig. 12: Posts data biathlonnmnm.cz on January $2^{\text {nd }}$

Source: Instagram page biathlonnmnm.cz 


\section{CONCLUSION}

This study presents the Double Diamond framework as one of the best options for creating a communication strategy. Apart from the precise methodological description, it also illustrates concrete examples of individual steps of this framework.

The framework is consists of four phases: Research phase, Synthesis phase, Ideation phase and Implementation phase. An important part of the whole process is a facilitator, who moderates, determines and monitors the time span of individual tasks and coordinates the colleagues. This communication strategy involved a total of four people.

Even prior to launching the strategy, it is necessary to set goals that will define the success of the project. Each communication strategy is based on a detailed analysis of the internal and external environment. In the case of focusing on the internet, we can use input data from tools like Google Analytics and individual social media reports. The often-neglected part of communication strategies are precisely defined customers to whom communication is directed. In this case - the personas, who are complemented by a customer journey.

The creative part of the model then offers a variety of opportunities to differentiate from its own previous strategies and to differentiate itself from the competition.

It is also necessary to consider the time-consuming implementation of individual strategies. Just as it was in this case, several ideas were created that could not be realized due to time requirements. All approved ideas are then placed in an editorial plan and ready for publication.

\section{References}

Babich, N. (2017). Putting Personas to Work in UX Design. Retrieved from https://theblog.adobe.com/putting-personas-towork-in-ux-design-what-they-are-and-why-theyre-important/.

Bland, D. (2016). What Is an Empathy Map? Retrieved from: https://www.solutionsiq.com/resource/blog-post/what-is-anempathy-map/.

Boag, P. (2018). Customer Journey Mapping: Everything You Need to Know. Retrieved from: https://www.sailthru.com/marketing-blog/written-customer-journey-mapping-need-to-know/.

Business Dictionary (2019). Brainstorming - definition. Retrieved from: http://www.businessdictionary.com/definition/ brainstorming.html.

Hančl, J. (2017). Biatlonový Boom v České republice. Co za tím stojí? Retrieved from https://www.isport365.cz/zprava/biatlonovy-boom-v-ceske-republice-co-za-tim-stoji.

Libdesign (2018). Jak bychom mohli? Retrieved from http://libdesign.kisk.cz/metody/jak-bychom-mohli.

Líbal, K., \& Mikeš, P. (2016) Fanoušci byli úžasní, rozplýval se v Novém Městě suverén Fourcade. Retrieved from https://www. denik.cz/zimni_sporty/fanousci-byli-uzasni-rozplyval-se-v-novem-meste-suveren-fourcade-20161219.html.

Nessler, D. (2018). How to solve problems applying a Design Thinking, UX, HCD or any Creative Process from scratch V2. Retrieved from https://uxdesign.cc/how-to-solve-problems-applying-a-uxdesign-designthinking-hcd-or-any-design-processfrom-scratch-v2-aa16e2dd550b.

Přikrylová, J., \& Jahodová H. (2010). Moderní marketingová komunikace. Praha: Grada Publishing, a. s.

Rohini, S. (2018). Marketing Communication: Concept, Objectives, Process, Golden Rules and Components. Retrieved from http://www.businessmanagementideas.com/marketing/marketing-communication/marketing-communicationconcept-objectives-process-golden-rules-and-components-business-marketing/17662.

Stubbs, A. (2018).Double Diamond Model Expanded. Retrieved from https://medium.com/@austin_57472/double-diamondmodel-expanded-9fbcaa897d48.

Zbiejczuk Suchá, L. (2018). 100 metod. Retrieved from http://100metod.cz/.

\section{Corresponding author:}

Mgr. Michal Jilka

mjilka@mail.muni.cz

+420731540881 